\title{
Professional writing and publishing Resources for librarians
}

$\mathbf{W}$

e all write-sometimes because we want to, and sometimes because we have to. Journal articles edge us toward tenure; book reviews give guidance to other readers; newsletter articles share our stories. And then, of course, there's e-mail.

The following resources offer a sampling of sites useful to librarian-writers. Whether you're writing for a scholarly journal or a blog, there's likely to be a tool here that can help you manage the writing process, answer a grammar question, or steer you toward a suitable venue for publication. This is a collection of well-worn reference guides, shelved with some fresh and dynamic blogs, podcasts, and communities. Subscribe to the feeds, or dog-ear your favorites with your own browser bookmarks. And write away.

\section{Metasites}

- Library Success Wiki: Publishing and Speaking. The Publishing and Speaking section of Library Success: A Best Practices Wiki includes tips and links related to publishing in library and information science publications, speaking at conferences, negotiating contracts, and more. Join the community and add your favorite resources. Access: http://www. libsuccess.org/index.php?title=Publishing _and_Speaking.

- LibraryWriting Bookmarks. This delicious.com collection includes hundreds of annotated links to online resources for librarian-writers. Tags catch articles, metasites, blogs, podcasts, wikis, and other Web-based resources on writing, editing, and publishing, selected for their value to librarians. Topics range from book proposals to scholarly communication to grammar guides. Access: http:// delicious.com/LibraryWriting.

- The Researching Librarian. Compiled by librarian Beth Ashmore and colleagues,

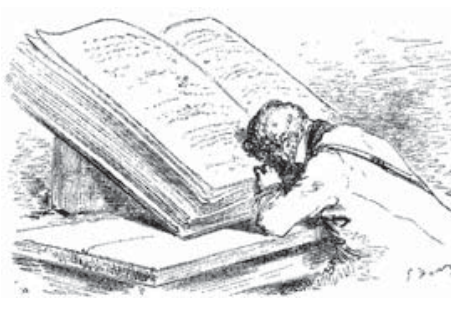
this site gathers selected Web resources that can be helpful to librarians doing research. The collection includes links to freely searchable citation and full-text databases, funding information, relevant journals, statistics and statistical methods, research tools, current awareness sources, and conference papers and proceedings. Access: http://www. researchinglibrarian.com.

\section{Opportunities}

- Beyond the Job. This active blog posts calls for papers and other professional development opportunities along with articles, news, and ideas on how to further your library career. Run by the "library job people," Sarah Johnson and Rachel Singer Gordon, Beyond the Job can help you stay informed and generate publication ideas. Access: http:// www.beyondthejob.org.

Laurie L. Putnam is communications consultant and lecturer in the School of Library and Information Science at San Jose State University, e -mail: laurielputnam@ gmail.com

(c) 2009 Laurie L. Putnam 
- A Library Writer's Blog. This blog helps librarians identify publishing and presentation opportunities by posting calls for papers, requests for presenters and reviewers, and other notices from the library world and related fields. Frequently updated (subscribers will receive about five posts a week) thanks to Corey Seeman of the University of Michigan. Access: http://librarywriting. blogspot.com.

- The Mortimore-Singh Guide to Publication in Library and Information Studies. Looking for the best place to publish your research? The Mortimore-Singh Guide profiles more
than 100
prominent
library and
information
science jour-
nals. Search-
able by title or subject, profiles include journal descriptions and links to associated Web sites and submission guidelines. Content is updated twice a year by Jeff Mortimore and Rohit Singh of the University of North CarolinaGreensboro. Access: http://www.uncg.edu /lis/PublicationGuide.

\section{How tos}

- Manage Your Writing. "In this knowledge economy," says author and writing consultant Ken Davis, "writing is the chief value-producing activity, and it can be managed like any other business process." Weekly blog posts from Davis, an English professor at Indiana University-Purdue University Indianapolis, present practical tips on managing your own writing process for better results. Access: http://www.manageyourwriting.com.

- Publish, Not Perish: The Art and Craft of Publishing in Scholarly Journals. This engaging and informative tutorial from the University of Colorado libraries introduces graduate students, early-career faculty, and

( The Art \& Craft of Publishing in Scholarly Journals other potential authors to the process of scholarly publishing, from getting ideas and choosing a journal to submitting and revising a manuscript. Five self-paced, interactive modules include worksheets, checklists, and samples of documents like cover letters and queries. Access: http://www.publishnotperish. org.

- SPARC Resources for Authors. The Scholarly Publishing and Academic Resources Coalition (SPARC) provides tools and materials that help authors understand options for sharing their research and retaining rights to their published articles. See especially the Author Rights brochure and the Author Addendum, "a legal instrument that authors may use to modify their publisher agreements, enabling them to keep selected key rights to their articles." Access: http://www.arl.org /sparc/author.

\section{Technique}

- Business Writing. This blog offers "talk, tips, and best picks for writers on the job” from Lynn Gaertner-Johnston of the consulting firm Syntax Training. Clear and informative posts use lots of work-oriented examples, providing tips on topics like writing effective e-mail messages and improving the clarity and precision of your communications. Sign up for the RSS feed and monthly e-mail newsletter. Access: http://www. businesswritingblog.com/business_writing.

- Grammar Girl. Grammar Girl Mignon Fogarty delivers "a fun and friendly dose of writing advice" on everything from punctuation and grammar to style and voice. Click on All Episodes for an archive of podcasts and transcripts, subscribe to the weekly podcast via iTunes or RSS, or sign up for an e-mail "tip of the day." Note that tips are based on common sense, modern usage, and a review of popular style guides. Occasionally, your guide may vary. Access: http:// grammar.quickanddirtytips. com. 
- Purdue Online Writing Lab (OWL). From Purdue University's English Department, the venerable OWL offers a wealth of writing resources and instructional materials for writers of all kinds. Content addresses the writing process, workplace writing, and grammar and mechanics; a full section offers guidance for non-native English speakers. Some items are available as podcasts, and readers can subscribe to a grammar blog. Access: http://owl.english.purdue.edu.

\section{Reference}

- Chicago Manual of Style Online. On the Web site for the Chicago Manual of Style, one of the most popular professional

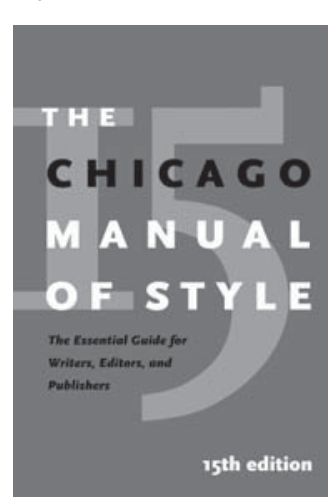

stylebooks, you'll find a quick guide to Chicago-style citation as well as a useful and surprisingly entertaining question-and-answer section. Review the latest queries, or browse Q\&A categories like, "Internet, Web, and Other Post-Watergate Concerns," "Commas," and "You Could Look It Up." Submit a question of your own, or subscribe to free monthly e-mail updates. $A c$ cess: http://www.chicagomanualofstyle.org.

- Merriam-Webster OnLine. The easyto-use Merriam Webster OnLine is based on the latest edition of Merriam-Webster's Collegiate Dictionary, a source frequently used by publishers that specify a dictionary. The online version includes the main $\mathrm{A}-\mathrm{Z}$ listing of the Collegiate Dictionary as well as the Abbreviations, Foreign Words and Phrases, Biographical Names, and Geographical Names sections of the book. Also included are 1,000 illustrations and 25 tables. Access: http://www.m-w.com/netdict.htm.

\section{Genres}

- Beginning Reporting. From writer, editor, and teacher Jim Hall, this Web site offers guides for interviewing and researching, writing, and rewriting news stories. While the in- formation is aimed at beginning reporters and their teachers, it can be useful to anyone writing for newsletters or magazines. "As I see it," says Hall, "a good reporter is like a pinball in play, always gathering, writing, revising, gathering, writing, revising-until time runs out." Sound familiar? Access: http://www.courses.vcu.edu/ENG-jeh/BeginningReporting /Introduction/home.htm.

- Elements for Basic Reviews. See the Collection Development section for "a guide for writers and readers of reviews of works in all mediums and genres" from ALA's Reference and User Services Association (RUSA). Guidelines are organized by genre, from reference works to musical recordings. Also included are examples of good and bad reviews; bibliographies of publications on writing, finding, and using reviews; and a list of publications that run reviews. Access: http:// www.ala.org/ala/mgrps/divs/rusa/archive /protools/referenceguide/default.cfm.

- Knight News Release Workshop. This Web site guides nonprofit organizations through the process of planning, writing, and polishing a clear and useful news release. Here you'll find tips for success, notes on things to avoid, and sample news releases. Sponsored by the Knight Foundation, which works "to ensure that each community's citizens get the information they need to thrive in a democracy." Access: http://www.knightcommunications.org /workshop/index.

- The OpEd Project. Op-eds, opinion pieces that traditionally run opposite the editorial pages of newspapers, provide "a gateway into public debate, feed all other

$$
\text { The pECProject } \begin{aligned}
& \text { media, and are } \\
& \text { a hub of thought } \\
& \text { leadership," ac- } \\
& \text { cording to the }
\end{aligned}
$$

OpEd Project. This initiative aims to expand our national conversation, in part by increasing the number of women represented in key print and online forums. Resources include submission information, writing tips, and sample articles. The organization also offers seminars and Webinars for universities, non- 
profits, corporations, and the public. Access: http://www.theopedproject.org.

- Writing for the Web. From Jakob Nielsen, "the king of usability," here's a collection of free columns and tips that discuss writing for the Web and describe how users read online. (Research reports are also available, for a price.) In "Writing Style for Print vs. Web," for example, Nielsen summarizes his key points: "Linear vs. non-linear. Authordriven vs. reader-driven. Storytelling vs. ruthless pursuit of actionable content. Anecdotal examples vs. comprehensive data. Sentences vs. fragments." Access: http://www.useit.com /papers/webwriting.

\section{Communities}

- NMRTWriter Listserv. NMRTWriter is an e-mail discussion group dedicated to supporting librarian-writers by sharing publishing opportunities, ideas, and knowledge. Hosted by the ALA New Members Round Table (NMRT), the group is open to all aspiring librarian-writers, new and experienced, from any type of library. Historically, traffic on this list has been light. Access: http://www.ala.org/ala/mgrps/rts/nmrt/ oversightgroups/comm/writers/ALA_print _layout_1_466759_466759.cfm.

- "Professional Writing" Message Board. Community message boards are now featured on LISjobs.com, a career site for information professionals managed by librarian-author Rachel Singer Gordon. The Professional Writing board, moderated by Kim Dority, publicizes calls for papers and invites librarians to post tips and questions on writing for the profession. Archives are open to the world, but you must register to post. Access: http://lisjobs.com/forum/yaf _topics19_Professional-Writing.aspx.

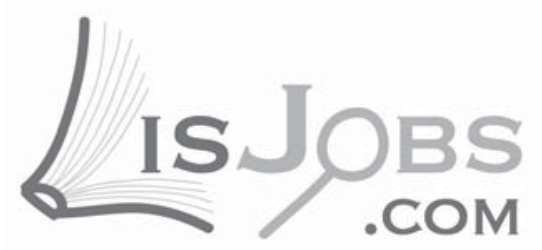

- WritersNet. A general-purpose writing community, WritersNet hosts writing resources, news, and discussions for authors, editors, publishers, and literary agents. The site provides an online directory of people in publishing along with articles and searchable discussion boards on writing, editing, and publishing topics. Many subjects are relevant to librarian-writers, especially those who want to publish creative or commercial work. Access: http://www.writers.net.

\section{Mentors}

- ACRL's “Your Research Coach" Program. ACRL's College Libraries Section offers a program for academic librarians seeking assistance with research and related projects that can lead to scholarly publications or presentations. Your Research Coach matches researcher-writers with "an experienced coach who can offer advice, support, and suggestions to improve the chances for success." Participants must be ACRL members. Access: http://www.ala.org/ala/mgrps /divs/acrl/about/sections/cls/collprogdisc /researchcoach.cfm.

- portal Mentor Program. The journal portal: Libraries and the Academy offers a postsubmission coaching program for new and developing authors. If a submitted manuscript is deemed "worthy but needs mentoring in order to be fully acceptable for publication in portal, " the author is offered an opportunity to work with a mentor to develop and resubmit the paper. "Over time," say portal editors, "we have seen this process produce very successful, even prize-winning results." Access: http://www.press.jhu.edu /journals/portal_libraries_and_the_academy /guidelines.html. $\approx$

\section{C\&RL News RSS}

Cover art, article links, and other valuable information from CERL News is now available by subscribing to our new RSS feed.

Point your Web browser to feeds. feedburner.com/candrlnews, and add our feed to your favorite reader, such as Bloglines or Google Reader. 